\title{
Effect of oils rich in linoleic acid on in vitro rumen fermentation parameters of sheep, goats and dairy cows $^{*}$
}

\author{
M. Szumacher-Strabel ${ }^{1}$, A. Cieślak and A. Nowakowska \\ Poznań University of Life Sciences, \\ Department of Animal Nutrition and Feed Management \\ Wotyńska 33, 60-637 Poznań, Poland
}

(Received 22 July 2008; revised version 21 January 2009; accepted 24 June 2009)

\begin{abstract}
The objective of this study was to investigate the effect of linoleic acid-rich plant oils on rumen fermentation parameters. Three experiments were carried out using the batch culture system. Ruminal inoculum was obtained from cannulated sheep, goats and dairy cows. The substrate for in vitro incubations was supplemented in the experimental groups with evening primrose (Oenothera biennis), borage (Borago officinalis) or Saint-Mary thistle (Silybum Marianum) seed oils to 5\% in substrate dry matter. High-linoleic oils improved protozoa counts in sheep and cows, and bacteria counts in goat rumens. Changes $(\mathrm{P}<0.05)$ of particular volatile fatty acid concentrations were noticed in all animal species. Advantageous changes were found in the level of total C18:1 trans in all species and in $t 11 \mathrm{C} 18: 1$ in goats and cows.
\end{abstract}

KEY WORDS: ruminants, plant oil, fermentation pattern, microbial population, in vitro

\section{INTRODUCTION}

Plant oils rich in unsaturated fatty acids may modify rumen fermentation; their effect depends on their fatty acid composition, origin, and degree of saturation. Unsaturated fatty acids are more toxic than saturated ones and can inhibit fermentation in the rumen more intensively (Jenkins, 1993). Oils as a

\footnotetext{
${ }^{*}$ Supported by funds from the Poznań University of Life Sciences

${ }^{1}$ Corresponding author: e-mail: mstrabel@jay.up.poznan.pl
} 
dietary supplement are usually used as sources of unsaturated fatty acids, mostly linoleic acid (LA), to increase the concentration of biohydrogenation intermediates, i.e. conjugated linoleic acids (CLA), and the trans vaccenic acid (VA) content in ruminant products. It has been well documented that CLA can be formed both ruminally by microbial activity during biohydrogenation of LA (Kepler et al., 1966) and endogenously from trans-vaccenic acid by the activity of $\Delta-9$ desaturase in tissues (Griinari et al., 2000). A relatively high concentration of LA in the diet can, however, both improve, but also inhibit biohydrogenation (Kim et al., 2000) because LA has been reported to have antimicrobial activity in the rumen (Hristov et al., 2005). The effect of LA depends on its concentration in the sum of fatty acids, that is, on the type of oil and diet used. Oils from evening primrose (Oenothera biennis), borage (Borago officinalis), or those obtained from the seeds of SaintMary thistle (Silybum Marianum) are rich in linoleic acid and, thus, may influence rumen fermentation. Sunflower and soyabean oils are commonly used as sources of energy and linoleic acid in animal nutrition and hence, broadly described in the literature. There is no information in the available literature on the effect of borage and Saint-Mary thistle oils on animal performance and rumen parameters. Strzetelski et al. (1998) described the effect of evening primrose oil cake on the milk fatty acid composition in dairy cows, and Reklewska et al. (2002) in milking goats. Jalč et al. (2005) presented the effect of evening primrose oil on rumen fermentation in vitro. Given that the effect of linoleic acid supplementation may depend on oil sources and that responses to such supplementation may differ considerably by species, the objective of this in vitro study was to determine the effects of evening primrose (EPO), borage (BO) and Saint-Mary thistle (SMO) oils on fermentation parameters in the environment of sheep, goat and cow rumens.

\section{MATERIAL AND METHODS}

\section{Inoculum and growth medium}

Three experiments were conducted. In the experiment 1 , ruminal contents were collected from $600 \mathrm{~kg}$ ruminally fistulated Polish Holstein-Friesian dairy cows maintained on a standard diet composed of $60 \%$ forage (lucerne silage and meadow hay) and $40 \%$ concentrate. In the experiment 2 , ruminal contents were collected from dairy sheep (cross of Polish Merino and East Frisian sheep; 20:80), whereas in experiment 3, from a cross of White Shorthaired goat and Saanen goat (37.5:62.5). Small ruminants were fed standard diets composed of meadow hay and concentrate $(60: 40 \%$ of dry matter) prepared according to the INRA system (IZ-INRA, 1993). Feeds and water were available ad libitum. Feed was delivered 
at 8.00 and 16.00 daily. In each experiment a similar procedure, according to Martin and Jenkins (2002), was used. Rumen fluid was collected $3 \mathrm{~h}$ after morning feeding. All animal procedures and protocols in this study were approved by the Local Animal Care Committee.

\section{Culture conditions}

Particle-free fluid and media were mixed and $40 \mathrm{ml}$ were anaerobically transferred to individual bottles (Fisher Scientific, Labo Baza Sp. z o.o. Suchy Las, Poland). The washing bottles contained $0.4 \mathrm{~g}$ substrate. The basic ration comprised meadow hay and maize meal $(60: 40 \%)$ for the control group. Experimental groups were supplemented with EPO, SMO (SEMCO ${ }^{\circledR}$ Specialized Seed Production and Processing Company, Poland) and BO (EFAVIT Institution of Vegetable Oil Expression and Natural Cosmetics Production, Poland), $5 \%$ in dry matter of the diet (17.4 mg of oil supplement). The fatty acid concentrations in oils are presented in Table 1. The substrate was incubated under anaerobic conditions at $39^{\circ} \mathrm{C}$ for $48 \mathrm{~h}$. The incubation time lasted $48 \mathrm{~h}$ to let microorganisms reach feed particles that were covered by oil supplemented to the substrate. Thebottles wereplacedina water bath and periodically mixed. Five flasks per group were used and each experiment was duplicated.

Table 1. Fatty acid composition of added oils: EPO - evening primrose oil, BO - borage oil, SMO - Saint-Mary thistle oil, FAME $1, \%$

\begin{tabular}{lrrr}
\hline Fatty acids & EPO & \multicolumn{1}{c}{ BO } & SMO \\
\hline SFA $^{2}$ & 7.96 & 24.28 & 14.25 \\
MUFA $^{3}$ & 7.41 & 27.32 & 30.93 \\
PUFA $^{4}$ & 84.63 & 48.40 & 54.82 \\
C18:0 stearic & 1.84 & 5.51 & 5.30 \\
C18: $1 n$-9 oleic & 7.11 & 24.86 & 25.50 \\
C18: $2 n$-6 linoleic & 84.47 & 45.32 & 52.47 \\
C18:3 $n$ - $3 \alpha$-linolenic & 0.16 & 0.24 & 1.77 \\
\hline
\end{tabular}

${ }^{1}$ fatty acid methyl esters; ${ }^{2}$ saturated fatty acids; ${ }^{3}$ monounsaturated fatty acids; ${ }^{4}$ polyunsaturated fatty acids

\section{Sampling and analysis}

After $48 \mathrm{~h}$ of incubation, a needle and syringe were used to anaerobically remove $7 \mathrm{ml}$ of culture samples through the butyl rubber stopper of each gas washing bottle from the batch culture system and $\mathrm{pH}$ was measured. An additional $3.6 \mathrm{ml}$ of rumen fluid and $0.4 \mathrm{ml} \mathrm{HgCl}_{2}$ were added and the mixture analysed for volatile fatty acid (VFA) contents. The concentration of VFAs after $48 \mathrm{~h}$ fermentation was determined by gas chromatography (VARIAN CHROMAPACK, CP-3380) 
according to Tangerman and Nagengast (1996). Fatty acid methyl esters were analysed by gas chromatography (VARIAN CHROMAPACK, CP-3380) using a flame ionization detector (FID) and Chrompac CP-Sil 88 column $(100 \mathrm{~m}, 0.25 \mathrm{~mm}$, $0 \cdot 2 \mu \mathrm{m}$ film thickness, Varian). Ultra-high-purity helium was used as the carrier gas at a constant flow rate of $30.0 \mathrm{ml} / \mathrm{min}$. Two $\mu \mathrm{l}$ of each sample were injected by splitless mode. The splitting ratio to the flame ionization detector was 1:90. The reaction temperatures were programmed as follows: initial $145^{\circ} \mathrm{C}$ for $9 \mathrm{~min}$, then increasing at $4^{\circ} \mathrm{C} / \mathrm{min}$ to $240^{\circ} \mathrm{C}$ (Cieślak et al., 2009). Fatty acid peaks were identified by comparison with the retention times of known standards (37 FAME Mix, Supelco, Poole, England and $c 9, t 11-18: 2$, Matreya, Pleasant Gap, PA, USA). The fatty acid profile was expressed as a percentage of total fatty acid methyl esters (FAME \%). Ammonia was quantified spectrophotometrically using the modified Nessler method as described by Szumacher-Strabel et al. (2002). Samples for ciliate counts were collected after $48 \mathrm{~h}$ fermentation and fixed with an equal volume of $8 \%$ formaldehyde solution. Ciliates were counted under a light microscope according to Coleman (1978). Bacteria were counted using Thoma chambers.

The obtained data (separately for each experiment) were subjected to variance analysis using the general linear model (GLM) procedure of SAS (2006). Multiple comparisons among means were carried out by Duncan's test. Significance was declared at $\mathrm{P}<0.05$.

\section{RESULTS}

\section{Experiment 1}

Ruminal fermentation parameters of the cow rumen are presented in Tables 2 and 3. All effects were analysed in comparison with the control group without oil supplementation. In this experiment, oil supplements did not change the total VFA concentrations (Table 2), which were stable in all oil-supplemented groups, but changes in individual fatty acid contents were noted. BO and SMO supplements decreased $(\mathrm{P}<0.05)$ isobutyrate concentrations in comparison with the control group; isovalerate concentrations were also statistically decreased by SMO treatment in comparison with the control. Numbers of protozoa were depressed $(\mathrm{P}<0.05)$ by the inclusion of $\mathrm{BO}$, whereas changes in bacteria counts were only numerical (Table 3). The effects of different plant oils on fatty acid concentrations in the rumen fluid after fermentation are summarized in Table 4. Both EPO and SMO treatments increased the concentration of total C18:1 trans fatty acids. All three sources of LA supplements tended to cause a statistically significant $(\mathrm{P}<0.05)$ increase in VA concentrations. The observed increase in 
monounsaturated fatty acids resulted from the improvement in total C18:1 trans, including VA. The MUFA concentration was statistically affected by treatments $\mathrm{BO}$ and SMO.

Table 2. Level of volatile fatty acid in the rumen fluid after incubation in vitro

\begin{tabular}{|c|c|c|c|c|c|c|}
\hline Item & $\begin{array}{c}\mathrm{C} \\
\mathrm{n}=3\end{array}$ & $\begin{array}{c}\mathrm{EPO} \\
\mathrm{n}=3\end{array}$ & $\begin{array}{l}\mathrm{BO} \\
\mathrm{n}=3\end{array}$ & $\begin{array}{c}\mathrm{SMO} \\
\mathrm{n}=3\end{array}$ & $\mathrm{SE}$ & P-value \\
\hline $\begin{array}{l}\text { Cows - Experiment I } \\
\text { total volatile fatty acid,mmol/1 }\end{array}$ & 72.17 & 72.07 & 71.48 & 73.33 & 0.39 & 0.4507 \\
\hline $\begin{array}{l}\text { volatile fatty acid, \% of total } \\
\text { acetate (A) }\end{array}$ & 60.96 & 60.83 & 60.83 & 60.96 & 0.08 & 0.9475 \\
\hline propionate $(\mathrm{P})$ & 17.05 & 17.14 & 18.10 & 17.90 & 0.25 & 0.3652 \\
\hline isobutyrate & $2.70^{\mathrm{a}}$ & $2.66^{\mathrm{ab}}$ & $2.56^{\mathrm{b}}$ & $2.44^{\mathrm{c}}$ & 0.03 & 0.0030 \\
\hline butyrate & 15.26 & 15.29 & 14.73 & 15.06 & 0.17 & 0.7058 \\
\hline isovalerate & $2.37^{\mathrm{a}}$ & $2.28^{\mathrm{ab}}$ & $2.12^{\mathrm{a}}$ & $2.06^{\mathrm{b}}$ & 0.05 & 0.0659 \\
\hline valerate & 1.66 & 1.70 & 1.66 & 1.57 & 0.03 & 0.5399 \\
\hline acetate/propionate $(\mathrm{A} / \mathrm{P})$ & 3.58 & 3.56 & 3.37 & 3.42 & 3.69 & 0.3637 \\
\hline $\begin{array}{l}\text { Sheep - Experiment II } \\
\text { total volatile fatty acid } \mathrm{mmol} / \mathrm{l}\end{array}$ & 48.91 & 52.00 & 47.50 & 54.07 & 1.20 & 0.2076 \\
\hline $\begin{array}{l}\text { volatile fatty acid, \% of total } \\
\text { acetate (A) }\end{array}$ & 55.33 & 56.04 & 55.59 & 55.47 & 0.14 & 0.3523 \\
\hline propionate $(\mathrm{P})$ & 30.30 & 30.19 & 30.06 & 30.22 & 0.12 & 0.9364 \\
\hline isobutyrate & $2.10^{\mathrm{a}}$ & $1.98^{\mathrm{b}}$ & $1.98^{\mathrm{b}}$ & $1.88^{\mathrm{b}}$ & 0.03 & 0.0074 \\
\hline butyrate & $10.17^{\mathrm{a}}$ & $9.64^{\mathrm{b}}$ & $10.20^{\mathrm{a}}$ & $10.33^{\mathrm{a}}$ & 0.10 & 0.0412 \\
\hline isovalerate & 0.77 & 0.77 & 0.78 & 0.72 & 0.01 & 0.5163 \\
\hline valerate & 1.34 & 1.38 & 1.39 & 1.38 & 0.02 & 0.9300 \\
\hline acetate/propionate $(\mathrm{A} / \mathrm{P})$ & 1.83 & 1.86 & 1.85 & 1.84 & 0.01 & 0.3523 \\
\hline $\begin{array}{l}\text { Goats - Experiment III } \\
\text { total volatile fatty acid } \mathrm{mmol} / \mathrm{l}\end{array}$ & 45.77 & 49.86 & 49.05 & 48.37 & 0.99 & 0.5534 \\
\hline $\begin{array}{l}\text { volatile fatty acid, \% of total } \\
\text { acetate (A) }\end{array}$ & 55.65 & 55.10 & 57.71 & 57.23 & 0.59 & 0.3745 \\
\hline propionate $(\mathrm{P})$ & 32.14 & 31.56 & 28.31 & 28.69 & 0.97 & 0.4329 \\
\hline isobutyrate & 2.40 & 2.98 & 2.26 & 2.30 & 0.14 & 0.2567 \\
\hline butyrate & 8.93 & 9.37 & 10.22 & 10.43 & 0.68 & 0.8859 \\
\hline isovalerate & 0.33 & 0.39 & 0.53 & 0.54 & 0.04 & 0.2270 \\
\hline valerate & $0.54^{\mathrm{b}}$ & $0.60^{\mathrm{b}}$ & $0.96^{\mathrm{a}}$ & $0.80^{\mathrm{ab}}$ & 0.07 & 0.0712 \\
\hline acetate/propionate $(\mathrm{A} / \mathrm{P})$ & 1.75 & 1.78 & 2.04 & 1.99 & 0.06 & 0.3169 \\
\hline
\end{tabular}

C - control; EPO - evening primrose oil; BO - borage oil; SMO - Silybum Marianum oil; $\mathrm{SE}$ - standard error; means with the same letters are not significantly different ${ }^{\mathrm{a}, \mathrm{b}}-\mathrm{P}<0.05$

\section{Experiments 2 and 3}

The ruminal fermentation parameters of sheep and goats are presented in Tables 2 and 3, respectively. Oil supplementation did not change the total volatile fatty acid concentrations in any rumen inocula, but some changes, in 
particular in individual fatty acids, were observed in the sheep and goat rumen fluid after incubation (Table 2). Concentrations of isobutyrate were decreased $(\mathrm{P}<0.05)$ in the sheep rumen in relation to the control when EPO, BO and SMO were included, whereas providing EPO decreased $(\mathrm{P}<0.05)$ butyrate in comparison with the control. Borage oil significantly increased $(\mathrm{P}<0.05)$ the valerate concentration in the goat rumen fluid after incubation. A significant $(\mathrm{P}<0.05)$ decrease in the $\mathrm{pH}$ of goat inoculum was observed when BO and SMO were supplemented to the substrate (Table 3). The ammonia concentration in goat rumen was not

Table 3. Effect of oil supplement on in vitro fermentation pattern and microbial population in the rumen fluid after incubation

\begin{tabular}{|c|c|c|c|c|c|c|}
\hline Item & $\begin{array}{c}C \\
\mathrm{n}=3\end{array}$ & $\begin{array}{c}\text { EPO } \\
n=3\end{array}$ & $\begin{array}{l}\mathrm{BO} \\
\mathrm{n}=3\end{array}$ & $\begin{array}{c}\text { SMO } \\
n=3\end{array}$ & SE & P-value \\
\hline \multicolumn{7}{|l|}{ Cows - Experiment I } \\
\hline $\mathrm{pH}$ & 6.44 & 6.49 & 6.35 & 6.33 & 0.02 & 0.0086 \\
\hline $\mathrm{N}-\mathrm{NH}_{3} \mathrm{mmol} / \mathrm{l}$ & 31.49 & 30.35 & 28.37 & 29.51 & 0.75 & 0.5698 \\
\hline bacteria $10^{7} \mathrm{ml}^{-1}$ & 13.67 & 11.17 & 10.83 & 10.50 & 0.62 & 0.2729 \\
\hline protozoa $10^{3} \mathrm{ml}^{1}$ & $165.80^{\mathrm{a}}$ & $144.68^{\mathrm{ab}}$ & $116.03^{b}$ & $142.07^{\mathrm{ab}}$ & 6.46 & 0.0226 \\
\hline \multicolumn{7}{|c|}{ Sheep - Experiment II } \\
\hline $\mathrm{pH}$ & 6.40 & 6.38 & 6.40 & 6.31 & 0.02 & 0.2464 \\
\hline $\mathrm{N}-\mathrm{NH}_{3} \mathrm{mmol} / \mathrm{l}$ & 12.58 & 12.15 & 12.65 & 12.67 & 0.45 & 0.9822 \\
\hline bacteria $10^{7} \mathrm{ml}^{-1}$ & 6.50 & 7.33 & 11.00 & 11.17 & 1.13 & 0.3608 \\
\hline protozoa $10^{3} \mathrm{ml}^{1}$ & $16.49^{\mathrm{b}}$ & $15.05^{\mathrm{b}}$ & $21.70^{\mathrm{a}}$ & $22.86^{\mathrm{a}}$ & 1.15 & 0.0073 \\
\hline \multicolumn{7}{|c|}{ Goats - Experiment III } \\
\hline $\mathrm{pH}$ & $6.45^{\mathrm{a}}$ & $6.44^{\mathrm{a}}$ & $6.27^{\mathrm{c}}$ & $6.36^{\mathrm{b}}$ & 0.02 & 0.0006 \\
\hline $\mathrm{N}-\mathrm{NH}_{3} \mathrm{mmol} / \mathrm{l}$ & 11.48 & 11.10 & 11.06 & 9.48 & 0.40 & 0.3263 \\
\hline bacteria $10^{7} \mathrm{ml}^{-1}$ & $9.50^{\mathrm{a}}$ & $4.83^{b}$ & $6.67^{\mathrm{ab}}$ & $6.50^{\mathrm{b}}$ & 0.70 & 0.0973 \\
\hline protozoa $10^{3} \mathrm{ml}^{1}$ & 14.76 & 17.94 & 17.65 & 17.36 & 1.27 & 0.8490 \\
\hline
\end{tabular}

affected $\mathrm{P}<0.05$ ) by dietary treatments; however, numerically decreased ammonia concentrations in oil-supplemented groups were observed (Table 3). In the sheep rumen, protozoa counts were significantly higher only when BO and SMO were supplemented, whereas EPO, BO and SMO treatments in goat inocula tended to increase protozoa counts, but these increases were not significant (Table 3). The bacteria counts were depressed in all experimental groups in goat rumen fluid, but statistically significant differences were found between the control and EPO groups (Table 3 ).

The effects of different plant oils on the fatty-acid profile in the rumen fluid after fermentation are summarized in Table 4 (sheep and goats). Individually, $\mathrm{EPO}, \mathrm{BO}$ and $\mathrm{SMO}$ affected $(\mathrm{P}<0.05) \mathrm{C} 18: 0$ and total $\mathrm{C} 18: 1$ trans concentrations 
Table 4. Level of fatty acids (\% FAME) in the rumen fluid after incubation in vitro

\begin{tabular}{|c|c|c|c|c|c|c|}
\hline Item & $\begin{array}{c}\mathrm{C} \\
\mathrm{n}=3\end{array}$ & $\begin{array}{c}\text { EPO } \\
n=3\end{array}$ & $\begin{array}{l}\mathrm{BO} \\
\mathrm{n}=3\end{array}$ & $\begin{array}{c}\text { SMO } \\
n=3\end{array}$ & SE & P-value \\
\hline \multicolumn{7}{|l|}{ Cows - Experiment I } \\
\hline C18:0 & $53.25^{\mathrm{ab}}$ & $55.00^{\mathrm{ab}}$ & $50.44^{\mathrm{b}}$ & $57.88^{\mathrm{a}}$ & 1.15 & 0.1198 \\
\hline total $\mathrm{C} 18: 1$ & 12.85 & 15.58 & 17.78 & 16.99 & 0.71 & 0.0380 \\
\hline total $\mathrm{C} 18: 1 \mathrm{cis}$ & 4.97 & 4.25 & 8.31 & 6.05 & 0.73 & 0.2335 \\
\hline total C18:1 trans & $7.88^{\mathrm{b}}$ & $11.61^{\mathrm{a}}$ & $9.47^{\mathrm{ab}}$ & $10.95^{\mathrm{a}}$ & 0.51 & 0.0158 \\
\hline $\mathrm{VA}^{1}$ & $4.97^{\mathrm{b}}$ & $7.88^{\mathrm{a}}$ & $6.64^{\mathrm{a}}$ & $7.31^{\mathrm{a}}$ & 0.43 & 0.0187 \\
\hline $\mathrm{C} 18: 2 \mathrm{c} 9 \mathrm{c} 12$ & 3.19 & 2.19 & 3.04 & 2.40 & 0.22 & 0.3516 \\
\hline $\mathrm{CLA}^{2} \mathrm{c} 9 \mathrm{t} 11$ & 0.16 & 0.15 & 0.07 & 0.07 & 0.02 & 0.0293 \\
\hline $\mathrm{C} 18: 3 \mathrm{c} 9 \mathrm{c} 12 \mathrm{c} 15$ & 1.09 & 0.87 & 0.82 & 0.87 & 0.04 & 0.2155 \\
\hline $\mathrm{SFA}^{3}$ & 78.71 & 77.56 & 74.05 & 75.39 & 0.83 & 0.1837 \\
\hline MUFA $^{4}$ & $16.69^{\mathrm{b}}$ & $19.08^{\mathrm{ab}}$ & $21.58^{\mathrm{a}}$ & $20.89^{\mathrm{a}}$ & 0.73 & 0.0487 \\
\hline PUFA $^{5}$ & 4.60 & 3.36 & 4.38 & 3.72 & 0.26 & 0.3476 \\
\hline \multicolumn{7}{|l|}{ Sheep - Experiment II } \\
\hline C18:0 & $22.09^{b}$ & $26.90^{\mathrm{a}}$ & $25.44^{\mathrm{ab}}$ & $30.01^{\mathrm{a}}$ & 1.03 & 0.0216 \\
\hline total $\mathrm{C} 18: 1$ & 18.35 & 22.94 & 19.30 & 17.89 & 1.25 & 0.5320 \\
\hline total $\mathrm{C} 18: 1 \mathrm{cis}$ & 13.32 & 15.97 & 11.06 & 8.09 & 1.31 & 0.1724 \\
\hline total C18:1 trans & $5.03^{\mathrm{b}}$ & $6.76^{\mathrm{ab}}$ & $8.23^{\mathrm{ab}}$ & $9.80^{\mathrm{a}}$ & 0.72 & 0.0809 \\
\hline $\mathrm{VA}^{1}$ & 3.84 & 5.02 & 6.49 & 7.45 & 0.64 & 0.1997 \\
\hline $\mathrm{C} 18: 2 c 9 c 12$ & 8.73 & 6.42 & 7.33 & 5.97 & 0.51 & 0.2397 \\
\hline $\mathrm{CLA}^{2} c 9 t 11$ & 0.19 & 0.22 & 0.20 & 0.68 & 0.11 & 0.3724 \\
\hline $\mathrm{C} 18: 3 c 9 c 12 c 15$ & 1.60 & 1.29 & 1.30 & 1.34 & 0.07 & 0.4130 \\
\hline $\mathrm{SFA}^{3}$ & 65.04 & 63.27 & 64.81 & 68.35 & 0.92 & 0.2775 \\
\hline MUFA $^{4}$ & 24.98 & 28.81 & 26.29 & 23.37 & 1.22 & 0.5049 \\
\hline PUFA $^{5}$ & 10.63 & 7.92 & 8.89 & 8.24 & 0.57 & 0.3846 \\
\hline \multicolumn{7}{|c|}{ Goats - Experiment III } \\
\hline C18:0 & $20.95^{\mathrm{ab}}$ & $16.99^{\mathrm{c}}$ & $18.50^{\mathrm{bc}}$ & $23.31^{\mathrm{a}}$ & 0.85 & 0.0130 \\
\hline total $\mathrm{C} 18: 1$ & 23.91 & 28.97 & 29.89 & 27.96 & 1.15 & 0.2918 \\
\hline total $\mathrm{C} 18: 1 \mathrm{cis}$ & 14.63 & 11.16 & 14.11 & 12.78 & 0.59 & 0.1533 \\
\hline total C18:1 trans & $9.28^{\mathrm{b}}$ & $17.81^{\mathrm{a}}$ & $15.78^{\mathrm{a}}$ & $15.18^{\mathrm{ab}}$ & 1.24 & 0.0553 \\
\hline $\mathrm{VA}^{1}$ & $7.35^{\mathrm{b}}$ & $8.74^{\mathrm{a}}$ & $7.70^{\mathrm{b}}$ & $7.64^{\mathrm{b}}$ & 1.08 & 0.0638 \\
\hline $\mathrm{C} 18: 2 c 9 c 12$ & $9.00^{\mathrm{b}}$ & $14.88^{\mathrm{a}}$ & $12.50^{\mathrm{ab}}$ & $12.15^{\mathrm{ab}}$ & 0.44 & 0.6572 \\
\hline $\mathrm{CLA}^{2} c 9 t 11$ & 0.44 & 0.42 & 0.56 & 0.68 & 0.05 & 0.3460 \\
\hline $\mathrm{C} 18: 3 c 9 c 12 c 15$ & $2.33^{\mathrm{a}}$ & $1.66^{\mathrm{b}}$ & $1.71^{\mathrm{b}}$ & $1.56^{\mathrm{b}}$ & 0.10 & 0.0025 \\
\hline $\mathrm{SFA}^{3}$ & 58.14 & 54.60 & 54.47 & 57.11 & 1.10 & 0.6165 \\
\hline MUFA $^{4}$ & 30.21 & 34.63 & 35.50 & 33.35 & 1.00 & 0.2746 \\
\hline PUFA $^{5}$ & 11.64 & 10.77 & 10.03 & 9.55 & 0.49 & 0.5168 \\
\hline
\end{tabular}

C - control; EPO - evening primrose oil; BO - borage oil; SMO - Silybum Marianum oil;

SE - standard error; ${ }^{1}$ VA - trans vaccenic acid; ${ }^{2} \mathrm{CLA}$ - conjugated linoleic acid; ${ }^{3} \mathrm{SFA}$ - saturated fatty acids; ${ }^{4}$ MUFA - monounsaturated fatty acids; ${ }^{5}$ PUFA - polyunsaturated fatty acids; means with the same letters are not significantly different ${ }^{\mathrm{a}, \mathrm{b}}-\mathrm{P}<0.05$

in the sheep rumen fluid after incubation. When compared with the control, EPO and SMO tended to increase C18:0 concentrations, also SMO increased total C18:1 trans concentrations. VA concentrations in the sheep rumen 
fluid were numerically, not significantly, higher in comparison with the control and increased by 30, 69 and 94\% in the groups with EPO, BO and SMO, respectively. In goat rumen fluid after $48 \mathrm{~h}$ of in vitro incubation, the amount of $\mathrm{C} 18: 0$ was lower $(\mathrm{P}<0.05)$ with EPO. An increase in total $\mathrm{C} 18: 1$ trans was noticed in the EPO and $\mathrm{BO}$ groups in comparison with the control. EPO treatment increased $(\mathrm{P}<0.05)$ VA concentrations in comparison with the control by almost $20 \%$, whereas differences in the $\mathrm{BO}$ and $\mathrm{SMO}$ groups were only numerically higher. The concentrations of conjugated isomers of $\mathrm{C} 18: 2$ were not affected in either sheep or goat rumen fluid after incubation

\section{DISCUSSION}

This study was conducted to determine the effect of plant oil supplementation on rumen fermentation parameters in three ruminant species. High-linoleic oils are usually considered inhibitors of rumen fermentation processes, affecting, for example, carbohydrate digestion (Doreau and Chilliard, 1997). The described effect is usually connected with depressed VFA production and lower acetate-topropionate ratio. In the present experiments, supplementing $5 \%$ of plant-derived fats did not disturb rumen fermentation in this respect. Concentrations and ratios of acetic to propionic acid also were not changed by evening primrose, borage or Saint-Mary thistle oil supplementation. The sum of VFAs was not affected, whereas some changes in individual VFAs were observed in all three tested animal species.

In experiment 1, borage oil and Saint-Mary thistle oil decreased the level of isobutyrate in dairy cow rumen fluid after incubation. Saint-Mary thistle oil supplementation also decreased the level of isovalerate. According to Wolin et al. (1997) these changes may also be connected with decreased ruminal microbe numbers and reduced proteolysis. A similar effect was observed by Hristov et al. (2005) who determined the effect of safflower oil on rumen fermentation in finishing cattle, although protozoal counts were only numerically decreased with the linoleic acid source. In our research, protozoa counts in cow rumen fluid after incubation decreased in all groups receiving oil supplements, but only in BO was the decline statistically significant. Also in experiments carried out by Hristov et al. (2004), when pure individual fatty acids were supplemented to barley-based diets in vitro, linoleic acid was effective at reducing protozoal numbers. Szumacher-Strabel et al. (2004), evaluating the effect of oils differing in fatty-acid composition (rape seed, sunflower and linseed), observed that the higher the number of unsaturated bonds in fatty acids present in supplemented oils, the higher the decrease in the butyrate concentration and protozoa counts. Whereas, Váradyová et al. (2007) 
showed that $5 \%$ of the dietary dry matter of sunflower seed oil (including $53 \%$ of C18:2) supplements to sheep diets decreased $(\mathrm{P}<0.05)$ only some protozoa species (Isotricha spp. and Eremoplastron dilobum), without significantly affecting total protozoa concentrations. In another study by Kišidayová et al. (2006), 5\% of evening primrose oil (containing $81 \%$ of $\mathrm{C} 18: 2$ ) elevated the total concentration and counts of some protozoa species (Entodinium spp. and Diploplastron affine by 32 and $21 \%$, respectively), in contrast to $39,46,100$ and $90 \%$, reductions of Dasytricha ruminantium, Eremoplastron dilobum, Polyplastron multivesiculatum and Isotricha spp. populations, respectively. The authors pointed out that rumen ciliates had no uniform response to oil supplements in in vitro studies, which also might explain the differences in our results (sheep and goat). Furthermore, Cieślak et al. (2006) stressed that vegetable oils differently affected the rumen ciliate Eremoplastron dilobum, grown in vitro. Additionally, an unpublished study of ours indicates that the effect of linoleic acid depended on the dose and form of the supplement.

Our results also highlight that source of rumen fluid (sheep, goat or cow) may influence protozoa populations. In the presented study, the level of protozoa in dairy cow rumen fluid after in vitro incubation was almost ten times higher than in small ruminants, both in the control and in the experimental groups. The type of diets fed to lactating dairy cows, among others the inclusion of silage, may explain this.

In the second experiment, evening primrose oil reduced the concentration of butyrate in sheep rumen fluid after incubation, whereas the lower concentrations of isobutyrate were observed with all of the applied high-LA oils. Reduced butyric concentrations are usually associated with reduced protozoa numbers and also with their depressed activity. The obtained results did not confirm this hypothesis.

The recorded decrease in butyrate was associated with increased protozoa counts. Some authors have suggested that if added dietary fat interferes with normal fibre digestion in the rumen, butyrate and acetate will always be reduced (Jalč and Čerešňáková, 2002).

In the third experiment, a statistically significant increase was observed in valerate concentration after supplementation of borage oil to in vitro goat diets.

According to Hristov et al. (2005), reduced protozoa counts can be associated with lowered concentrations of nitrogen ammonia. There are many conflicting data concerning ammonia concentrations when the diet is supplemented with fats: some of the data show no effect of supplemented fats on ammonia concentrations (Jalč et al., 2005), while other publications reported increases (Jalč et al., 2002) or decreases (Doreau et al., 1991) following such supplementations. No statistically significant changes were observed in the ammonia concentration in any of our three experiments. In the first experiment with cow rumen fluid, tendencies toward 
decreased ammonia concentrations and, simultaneously, reduced protozoa counts were observed. In small ruminants' rumen fluid after incubation, the concentration of ammonia was comparable in all groups.

Most in vitro studies with ruminal microorganisms and long-chain fatty acids have utilized batch culture techniques (Martin and Jenkins, 2002), because the most intensive changes in fatty acid concentrations, including formation of conjugated isomers of LA, occur in the first $24 \mathrm{~h}$ of incubation. One of the limiting factors for fatty acid formation is the extracellular $\mathrm{pH}$ that depends on the substrate type and concentration, and, in continuous culture or in vivo experiments, the dilution rate. According to Martin and Jenkins (2002), culture $\mathrm{pH}$ appears to have the most influence on the production of C18:1 trans and conjugated LA isomers. In our experiments, the $\mathrm{pH}$ was altered only in goat rumen fluid after incubation and decreased when borage oil or Saint-Mary thistle oil were supplemented. Fat in ruminant diets can change biohydrogenation of unsaturated fatty acids in the rumen, which is connected with reduced numbers of bacteria that carry out this process. A reduced number of total bacteria was observed in goat rumen fluid in all groups, whereas only EPO supplementation caused statistically significant differences. The main end product of biohydrogenation is stearic acid (C18:0). The lower concentration of this acid is due to incomplete biohydrogenation (Jalč et al., 2005) and thus increased levels of intermediates, such as trans vaccenic acid (C18:1 trans; VA) and conjugated linoleic acid isomers, are observed. Jalč et al. (2005) found that the concentration of the main biohydrogenation intermediates, CLA and VA, increased after evening primrose oil and borage oil supplementation to the diet and that the stearic acid concentration was decreased in all experimental groups in a Rusitec. According to Lock and Garnsworthy (2003), increased levels of CLA and VA are caused by the increased intake of biohydrogenation substrates: linoleic and $\alpha$-linolenic acid. In the experiment carried out by Abughazaleh et al. (2003), sunflower seeds supplemented to a dairy diet increased VA and c9t11CLA concentrations and decreased the concentration of stearic acid. In our experiments, the level of VA in the ruminal fluid increased when the incubated diets were supplemented with evening primrose, borage or Saint-Mary thistle oils when compared with the control groups. These effects were observed in all experiments with different inocula, but statistically significant differences were observed only in goat rumen fluid when EPO was supplemented and in cows when LA high oils were supplemented. Changes in VA in goats were followed by a decreased C18:0 level, whereas increased VA in the cows' inocula was not strongly connected with C18:0 alterations. The concentration of c9t11CLA in small ruminants was observed to increase after incubation in vitro with high-linoleic plant oils and to decrease in dairy cow rumen fluid. The latter phenomenon is difficult to explain. However, the observed changes were not statistically confirmed. The effect of fat 
on rumen fermentation depends on the type of fat, mostly on fatty acid saturation. The occurrence of C18:1 and C18:2 isomers depends on the dietary unsaturated fatty acid profile (Loor et al., 2002). In the case of the performed experiments, the origin of the rumen fluid rather than the type of fatty acids supplemented in the diet determined the concentration of long-chain fatty acids after fermentation.

\section{CONCLUSIONS}

In conclusion, the addition of oils rich in linoleic acid did not strongly influence rumen fermentation and up to $5 \%$ in dietary dry matter may be a valuable supplement for ruminants. The changes in the observed rumen fermentation patterns were in agreement with physiological standards. The probable inhibition of the final biohydrogenation step increased the level of intermediate products, especially trans vaccenic acid. The obtained results indicate that the supplementation of ruminant diets with plant oils rich in linoleic acid may improve the fatty acid composition of ruminant products, but the final result will depend on complex factors that should always be taken under consideration. The type of fat that was supplemented to experimental diets was reflected in the fermentation pattern and microbial population and, therefore, we uphold the hypothesis that species is the most important deciding factor. In the presented experiments, microbial features and fermentation parameters may have varied also according to different feeding systems between cows and small ruminants, whereas among cows, sheep and goats - according to species diversity. The response of cows and small ruminants to experimental factors should also be reviewed in future research applying the same basic ration to all animals, not only the same experimental substrate as in in vitro procedures. That will allow eliminating the effect of microbial population differences caused by feeding.

\section{REFERENCES}

AbuGhazaleh A.A., Schingoethe D.J., Hippen A.R., Kalscheur K.F., 2003. Conjugated linoleic acid and vaccenic acid in rumen, plasma and milk of cows fed fish oil and fats differing in saturation of 18 carbon fatty acid. J. Dairy Sci. 86, 3648-3660

Cieślak A., Machmüller A., Szumacher-Strabel M., Scheeder M.R.L., 2009. A note on comparison of two extraction methods used to quantify the $\mathrm{C} 18$ fatty acids in feed and digesta of ruminants. J. Anim. Feed Sci. 18, 362-367

Cieślak A., Miltko R., Bełżecki G., Szumacher-Strabel M., Potkański A., Kwiatkowska E., Michałowski T., 2006. Effect of vegetable oils on the methane concentration and population density of the rumen ciliate Eremoplastron dilobum grown in vitro. J. Anim. Feed Sci. 15, Suppl. $1,15-18$

Coleman G.S., 1978. Rumen entodiniomorphid protozoa. In: Methods of Cultivating Parasites in Vitro. London, Academic Press, pp. 39-54 
Doreau M., Chilliard Y., 1997. Digestion and metabolism of dietary fat in farm animals. Brit. J. Nutr. 78, Suppl. 1, S15-S35

Doreau M., Legay F., Bauchart D., 1991. Effect of source and level of supplemental fat on total and ruminal organic matter and nitrogen digestion in dairy cows. J. Dairy Sci. 74, 2233-2242

Griinari J.M., Corl B.A., Lacy S.H., Chouinard P.Y., Nurmela K.V.V., Bauman D.E., 2000. Conjugated linoleic acid is synthesized endogenously in lactating dairy cows by $\Delta 9$ desaturase. J. Nutr. 130, 2285-2291

Hristov A.N., Ivan M., McAllister T.A., 2004. In vitro effects of individual fatty acids on protozoal numbers and on fermentation products in ruminal fluid from cattle fed a high-concentrate, barley-based diet. J. Anim. Sci. 82, 2693-2704

Hristov A.N., Kennington L.R., McGuire M.A., Hunt C.W., 2005. Effect of diets containing linoleic acid- or oleic acid rich oils on ruminal fermentation and nutrient digestibility, and performance and fatty acid composition if adipose and muscle tissues of finishing cattle. J. Anim. Sci. 83, $1312-1321$

IZ-INRA, 1993. Standards for Cattle, Sheep and Goat Nutrition (in Polish). Research Institute of Animal Production. Omnitech Press, Warsaw

Jalč D., Čerešňáková Z., 2002. Effect of plant oils and malate on rumen fermentation in vitro. Czech J. Anim. Sci. 47, 106-111

Jalč D., Potkański A., Szumacher-Strabel M., Cieślak A., Čertic M., 2005. Effect of microbial oil, evening primrose oil and borage oil on rumen fermentation in vitro. Vet. Med.-Czech. 50, 480483

Jenkins T.C., 1993. Lipid metabolism in the rumen. J. Dairy Sci. 76, 3851-3863

Kepler C.R., Hirons K.P., McNeill J.J., Tove S.B., 1966. Intermediates and products of the biohydrogenation of linoleic acid by Butyrivibrio fibrisolvens. J. Biol. Chem. 241, 1350-1354

Kim Y.J., Liu R.H., Bond D.R., Russell J.B., 2000. Effect of linoleic acid concentration on conjugated linoleic acid production by Butyrivibrio fibrisolvens A38. Appl. Environ. Microbiol. 66, 52265230

Kišidayová S., Mihaliková K., Váradyová Z., Potkański A., Szumacher-Strabel M., Cieślak A., Čertik M., Jalč D., 2006. Effect of microbial oil, evening primrose oil, and borage oil on rumen ciliate population in artificial rumen (RUSITEC). J. Anim. Feed Sci. 15, Suppl. 1, 153-156

Lock A.L., Garnsworthy P.C., 2003. Seasonal variation in milk conjugated linoleic acid and $\Delta 9$ desaturase activity in dairy cows. Livest. Prod. Sci. 79, 47-59

Loor J.J., Bandara A.B.P.A., Herbein J.H., 2002. Characterization of C18:1 and C18:2 isomers produced during microbial biohydrogenation of unsaturated fatty acid from canola and soya bean oil in the rumen of lactating cows. J. Anim. Physiol. Anim. Nutr. 86, 422-432

Martin S.A., Jenkins T., 2002. Factors affecting conjugated linoleic acid and trans-C18:1 fatty acids production by mixed ruminal bacteria. J. Anim. Sci. 80, 3347-3352

Reklewska B., Ryniewicz Z., Góralczyk M., Kuczyńska B., Karaszewska A., Dziarski K., 2002. The effect of a diet containing evening primrose (Oenothera paradoxa) vs. whole linseed on the content of functional lipid fractions of goat milk. Anim. Sci. Pap. Rep. 20, 229-244

SAS $^{\circledR}, 2006$. SAS/STAT Users Guide. SAS Institute Inc. Cary, NC

Strzetelski J., Kowalczyk J., Krawczyk K., Stasiniewicz T., Lipiarska E., 1998. Evening primrose (Oenothera paradoxa) oil cake or ground rape seed supplement to diets for dairy cows. J. Anim. Feed Sci. 7, 365-375

Szumacher-Strabel M., Martin S.A., Potkański A., Cieślak A., Kowalczyk J., 2004. Changes in fermentation processes as the effect of vegetable oil supplementation in in vitro studies. J. Anim. Feed Sci. 13, Suppl. 1, 215-218 
Szumacher-Strabel M., Potkański A., Kowalczyk J., Cieślak A., Czauderna M., Gubała A., Jędroszkowiak P., 2002. The influence of supplement fat on rumen volatile fatty acid profile, ammonia and $\mathrm{pH}$ levels in sheep fed a standard diet. J. Anim. Feed Sci. 11, 577-587

Tangerman A., Nagengast F., 1996. A gas chromatographic analysis of fecal short fatty acids using the direct injection method. Anal. Biochem. 236, 1-8

Váradyová Z., Kišidayová S., Siroka P., Jalč D., 2007. Fatty acid profiles of rumen fluid from sheep fed diets supplemented with various oils and effect on the rumen ciliate population. Czech J. Anim. Sci. 52, 399-406

Wolin M.J., Mikker T.L., Steward C.S., 1997. Microbe-microbe interactions. In: P.N. Hobson, C.S. Steward (Editors). The Rumen Microbial Ecosystem. Blackie Academic and Professional, pp. 467-492 